\title{
The moment of screening: what nonfiction films can do
}

\author{
Nico de Klerk
}

$N u$ er meer materiaal beschikbaar komt, wordt het tijd om eens vanuit een kwantitatieve invalshoek te kijken naar de zo veronachtzaamde shorts. Over deze korte documentaire (voor)films - speciaal die welke werden getoond in de commerciële filmtheaters, in de jaren dertig - is nog wel het een en ander te vertellen. En dat vooral aan de hand van filmprogramma's, waarbinnen de shorts gebracht werden. Een beschouwing, gebaseerd op materiaal uit het Filmmuseum.

Histories of documentary film are incomplete. 'As long as they continue to focus on film only they always will be; after all, the documentary is the clearest example of a cross-media genre: the travelogue, for instance, was taken over whole cloth from magic lantern performances, and the newsreel, the wildlife film or the sports report have all become television productions. Yet, documentary cinema histories are incomplete as nonfiction films are usually dealt with in terms of artistic merit or perceived (linear) development; what remains the same is apparently uninteresting, despite the fact that from a stylistic point of view some documentary genres are characterized by a lack of change. Moreover, in so far as these are national film histories, they usually focus on commercially released domestic productions. As a result, non-commercial productions, such as amateur films, or the films that national audiences saw - whether domestic or foreign are ignored. Most of these histories - although, in fact, there are not even that many, certainly not many international ones - were written at a time when much less materials were accessible and available, in archives as well as in (specialized) festivals that rely wholly or partly on archival materials. ${ }^{2}$ But now that more material becomes available, it is time for a revision, a re-evaluation, unbiased by qualitative notions of auteur-ship, development (or worse: progress), etc. I would advocate a more quantitatively oriented historiography, i.e. one that reflects as much as possible what audiences in a given time or place were offered.

In order to fish out more material and get some perspective on how it was seen, a good starting point is the programme as an exhibition format. 
To my mind, the programme is one of the most, if not the most, underrated and under-researched aspects of the history of screen practice.' This lack of attention is all the more surprising when one realizes that until well into the 1960 s, here and there even into the early 1970s, in commercial cinemas in the Netherlands - and probably elsewhere -, film screenings were still part of a programme, including not only a number of films but also musical interludes and/or slide projections. At the same time in art cinemas, introductions by invited directors and discussions with audiences gave a new impetus to live aspects of cinema shows. Here, I want to focus on the so-called programme of shorts, particularly on some of the nonfiction genres it contained. I want to highlight some documentary films that are often overshadowed, in both archival and academic work, by materials that are accorded more prestige, be they fiction films, avant-garde, or more artistically accomplished and/or feature-length documentaries. As I will limit myself to programmes shown in commercial cinema theatres in the I930s, the latter category, in fact, plays a secondary role. Whether they were refused by commercial exhibitors or reserved for non-commercial venues, or both, the fame of the films that usually surface in histories of the documentary certainly didn't always rest on popular appeal.

\section{Inside the cinema}

For commercial cinemas, a requirement of the films that were shown in their programmes was that they have sufficient entertainment value. Not surprisingly; they were often produced by specialized units of the same companies that made the features. 'Entertainment', of course, is still not a word immediately associated with 'documentary' or 'nonfiction film'. Nevertheless, for all the genres the programme of shorts comprised entertainment appears to have been an important consideration; the shorts' variety, in its turn, may have contributed to the programme's entertaining character as well. I indeed use the word 'variety' with caution, because it is hard to find actual, complete line-ups of cinema programmes of this period, because both critical attention and publicity by this time focused almost exclusively on features or feature-length films; I'm not, then, implying that the various kinds of films I discuss all appeared in one programme.

Newsreels, at first glance the most factual of documentary films, are a good example of the way these shorts sought not just to inform, but also to please spectators. Almost all of the various newsreel series from this period - but not exclusively from this one - include lighter items, notably reports about sports matches or fashion shows, events, incidentally, that would have been known to occur well in advance. As a matter of fact, for 
more spontaneous events, newsreels are - I'm tempted to say: as a rule too late; items that claim to be about fires, for example, more often than not merely show the smoking remains of a fire spectators didn't see. If a newsreel contained items about more serious affairs, such as political events, it was usually restricted to ceremonial aspects, such as state visits or parades. Some series consisted even entirely of such lighter and less time-bound subjects. Although they copy the structure of the newsreel in that they combine a number of varied subjects, they can also be seen as a continuation of earlier, silent series that combined views of a number of interesting or exotic locations. ${ }^{4}$

A number of news films also exemplify what I consider to be a more typical, certainly more prominent, aspect of the programme of shorts of the early 1930s. Whereas news films almost by definition refer to a reality outside the cinema theatre, a number of early sound-on-film news shorts focus on events that relate to what happened, or what was going to happen, inside the theatre. That is to say that in addition to already established newsworthy publicity items, usually centring on film stars, ${ }^{5}$ film programmes increasingly included reports of the building of cinemas or opening nights as well as announcements of coming attractions. In fact, more genres in the programme of shorts reveal a comparable kind of referential shift. That is to say that these films take the reality around and within the cinema theatre as their reference: the building, the audience, the show or the programme itself is what they are about. ${ }^{6}$ Below I want to review a number of these genres and the various ways in which they accomplish this shift and how this affects the traditional notion of 'documentary'.

\section{Carlton Hotel}

Although in generic terms some of these types of film can be seen as a continuation of I920s silent cinema, judging from what is available in the Nederlands Filmmuseum's archive this referential shift seems to have become more prominent and more versatile with the coming of sound-onfilm shorts. In the I940s and I950s, again judging from what this archive holds, the number of these films seems to have dropped and the topics have become less varied. The introduction of sound, as is well-known, marked a change in the power relations between film exhibitors and film producers, favouring the latter by ensuring an increased standardization of film shows in terms of the conditions under which the films were screened: no simultaneous musical accompaniment or sound effects, invariable projection speed, less opportunity to remove or re-order scenes unnoticed. But the referential shift of some of these shorts points up another kind of standardization: 
increasingly, film screenings became coterminous with the entire show, as they replaced other forms of presentation. With the disappearance, certainly decrease, of live elements or of announcements on slides in the cinema theatre, films consequently took on tasks that they had not performed before (see the examples mentioned in note 6). Particularly the short films showing theatre managers announcing coming attractions in their theatre are somewhat paradoxical in this respect, as these films re-introduce a distinctive aspect in a theatre's programme, all the while using the very technology that limited a theatre's opportunities to distinguish itself.

If we accept the notion of referential shift, we may also have to adjust our understanding of 'documentary'; a mere change in subject matter is not sufficient to achieve this shift. It has been argued, notably by Steve Wurtzler, that sound-on-film records of speeches, as opposed to their silent counterparts, reinforce the documentary status of such events by 'foreground[ing] the fact that both the reproduced image and sound originated from a single, identifiable source at a specific, depicted time." 'Documentary' here means, quite literally, a document of a past event. Wurtzler, somewhat comically I think, supports his argument by referring to the unintelligibility of some of these films: in his view, what was being said was subordinate to the ability to record sound at all. But what I find interesting about some of these sound-on-film speeches, whether on the occasion of the opening of a cinema, a premiere or to wish the audience a happy New Year, is that they increasingly tend to imitate the situation inside a theatre, i.e. a specific, depicted place. A clear example of this is the film HR. TER LINDEN HOUDT INLEIDING, a spoken trailer in which the speaker announces two 'very special' premieres on the occasion of the first anniversary of the City Theatre in Amsterdam while standing in front of a curtain. Here, there are no specific temporal indications, and for a good reason: the film merely had to fill a particular slot in the programme, in order to pretend to greater effect that the film show had not begun yet.

Something similar occurs with musical shorts. These films, of course, also establish continuity with a practice of the silent era, even though they take advantage of the possibility of showing more than what had been common or possible in most cinema theatres: larger orchestras, more famous names and/or a more varied line-up of artists. Yet musical shorts, too, may have been more than just records of a musical performance. I take this suggestion from a musical short about the Dutch show and radio orchestra The Ramblers, the full title of which reads: THE RAMBLERS, ONDER LEIDING VAN THEO UDEN MASMAN UIT HET CARLTON HOTEL TE AMSTERdam. This is a telling title in that it reveals how this, and perhaps other shorts as well, may have been intended and perceived: as a quasi live, transmitted event. ${ }^{9}$ It suggests that the document-status of these and other 
films is perhaps not their main concern. Rather than evidence of preexisting events, rather than, that is, the moment of recording, it is the moment of screening which is distinctive to these films.

\section{Turn-taking}

In a number of essays on early nonfiction film William Uricchio proposed to consider some genres, such as phantom rides and the so-called rocks-andwaves films, in the context of nineteenth-century discourses on simultaneity, theories and fantasies sparked by the telephone and other inventions that brought what was very far very near in an instant, or seemingly in an instant. ${ }^{10}$ These discourses, in other words, prefigure a kind of live television transmission. He argued that these formally rather simple film subjects, which provided 'screen images of an experience essentially identical to coincident profilmic reality', could be seen as 'simulating simultaneity'. The fact that these films simulated simultaneity, simulated a sense of liveness, suggests that the idea of cinema was rather, perhaps, a detour towards television. Incidentally, this may also be true in a way of the efforts of screening filmed reports of newsworthy events as quickly as possible after their occurrence. It did not take long before these reports were screened only a couple of hours after the event - for decades the closest one could get to the ideal of direct moving images. 1930s textual trailers announcing footage of sports events to be screened 'soon in this theatre' are an echo of this practice." With the coming of sound, considerations of liveness and simultaneity seem to have reappeared - not surprisingly perhaps, because, after all, the idea of simultaneity began with inventions involving sound. This is probably also its last reappearance in film, because before long real television was introduced to the public.

There are other categories of shorts that take this suggestion of simultaneity one step further. These films not only address spectators directly and quasi-live, they also invite them to act, sometimes even to interact: to donate money, buy a lottery ticket, participate in a prize contest or answer a quiz-master's questions." Sing-alongs also fit in this category, even though they often have a fictional frame. These kinds of films are more accomplished, because the audience has been explicitly scripted into these films. Yet at the same time they appear to be more of a risk, because their effect, their success depends entirely on the cooperation of a - preferably - large number of co-present spectators. Here, then, the moment of screening is not just distinctive, but decisive: the films presuppose a kind of interaction, if not turn-taking, an alternation of moves that had been recorded with moves that had to be made on the spot, 'live' so to speak. 


\section{Symbiosis}

What, then, is the relevance of the programme format in all this? Obviously, the screening of these films was meant to give the programme of shorts a distinct attraction. Simulated simultaneity and inviting spectators to do something were largely restricted to these films, to these moments in the film show, although in musicals such moments could most likely recur. In other words, the entertainment of the programme of shorts was of a different quality, for which quality documentary film, notably documentaries in the extended sense of the term I have been arguing here, were to a significant extent responsible.

This is not to say that the shorts merely acted as a foil to the feature, although they certainly did that as well, given their modest artistic and technical accomplishments and the pervasiveness of stylistic aspects as direct address, frontal orientation, their compiling of other images, and their printed texts. But another interesting aspect, one that is connected to their reference to the world of the cinema theatre, is that such films are a sign of film as a performance, or rather regular performances; these films refer to, if not presuppose, the so-called viewing habit. These films helped to create a moment in the show in which the spectator was as it were taken aside, a moment in which the industry - not seldom through the filmed appearance of the theatre manager - tightens its bonds with the spectator by appealing to his knowledge and experience; direct address makes these moments indeed almost similar to theatrical asides. Trailers, for instance, do that by holding out the prospect of future attractions. The same genre, as well as newsreels items about film stars, also point backwards in time, by capitalizing on spectators' familiarity with a film star's career. ${ }^{\text {.' }}$

The performance character of cinema that these films point up is something which may not be uppermost in our minds when dealing with the sound era. Even though in the historiography of early and silent film, aspects of performance has come to be increasingly recognized and theorized - particularly musical accompaniment, lecturing and 'barking', cinema design and architecture -, it did, of course, not all of a sudden disappear with the coming of sound. These short films suggest quite directly that the 'performance area' of cinema extended beyond the screen to include the auditorium, extended beyond the individual film to include repeated visits to the cinema theatre.

In order to learn more about this, we will have to scrutinize not just films, but all kinds of sources, including memoirs and other 'ego documents' by contemporaries. Here, I just want to mention one example of indirect information: the programme booklet - another unpopular subject in film history. Usually the texts of these booklets are restricted to the main 
feature; only occasionally mention is made of an orchestra, who they are or what they play. For the rest, these often lavishly illustrated booklets are filled with extensive descriptions of the main feature's plot, with now and then an additional interview, the odd essayistic review or song lyrics in either the original language or in translation. The lyrics suggest, once again, that sound not only came from the film, but also from the auditorium. Furthermore, and interestingly, the extensive plot descriptions, often revealing the end, run contrary to received opinion about the classical feature film, particularly its suspense-driven narratives withholding information from the audience. It may come as a surprise that these booklets were produced by the production companies or their distributors, not by the exhibitors (another instance of standardization). Surely, they may also have been considered as souvenirs, particularly because of their pictures. But given the viewing habit, given the large number of theatres and the symbiosis of a steady stream of films and of audiences in the 1930s, this points to the relative - and I stress 'relative' - un-importance of the film screening. Particularly neighbourhood theatres were also places to meet, gossip and do all kinds of things quite unrelated to the screening. ${ }^{14}$ In other words, there may have been some kind of competition between film screenings and other events in the cinema. The descriptions in the programme booklet may, therefore, have been meant as a support to follow the story, either in advance or for latecomers. This sheds perhaps also another light on the documentary films I discussed, because in their own distinctive way they may have been meant to cope with this 'competition': instead of character development, interesting subject matter or suspense, these films address spectators directly in a way - quasi-live - that may, if only momentarily, have caused surprise, even confusion, but at least captured their attention (which may be one reason why these films were not announced in the booklets). One thing that this implies, of course, is that research into narrative and stylistic development should encompass not just the main feature, but the programme as a whole.

The way I conceived of documentary film here, stressing what they do rather than what they tell or document, does not, of course, exhaust the possibilities of documentary film. Nevertheless, by focusing on programmes rather than on individual films, I hope to have identified a neglected aspect of documentary film, an aspect, moreover, that probably was witnessed by infinitely more spectators than some of the supposed high points of the genre. ${ }^{15}$ 


\section{Notes}

I This article is an adaptation of a lecture given at the conference Triumph der Bilder, organized by the 'Haus des Dokumentarfilms', in Berlin in December 2000, and will also appear in the periodical in bookform, Close $U p$, published by that 'Haus'.

2 The classic histories, Richard M. Barsam's Nonfiction film: a critical history, originally published in 1973 (New York) and Erik Barnouw's Documentary: a history of the non-fiction film, originally published in 1974 (New York), may therefore be excused. However, more recent editions of these histories hardly make use of the changed archival policies and largely update the most recent developments.

3 The use of the word 'screen practice' should alert the reader to the fact that the programme is not a format uniquely associated with cinema; magic lantern shows and television point up that there is, if not a continuous tradition, then at least a continuity of tradition. The organization of items in various forms of theatre, musical performances and recordings or radio indicate the dimensions of the unexplored world of the programme.

4 Some series produced in Holland in the early I93Os were: ORION-REVUE, HOLLAND BEELD EN KLANK REVUE, EXPRESS KLANK REVUE, ACTUALITEITEN REVUE, or CENTRA VARIA. The words 'revue' and 'varia' would, of course, be more readily associated with entertainment than news. In fact, ACTUALITEITEN REVUE contained items that one would hardly consider to be actualities; no. 33 of its first series, in 1935 , contains items showing, respectively, a autumnal day, a watermill, a nature reserve, and a faked thunderstorm.

5 Some examples in the Nederlands Filmmuseum archive are: BEZOEK LILIAN HARVEY AAN NEDERLAND, FILMSTARS PRIVAT: LILIAN HARVEY, ZARAH LEANDER IN NEDERLAND, AANKOMST IN NEDERLAND VAN THEA VON HARBOU or newsreel items of Wallace Beery's visit to Volendam or Sidney and Charlie Chaplin's arrival in the Dutch East-Indies. The latter examples certainly continued a practice already popular in the silent era, in view of the Dutch items of Tom Mix's visit to Amsterdam, Mary Pickford and Douglas Fairbanks' visit to The Hague on their honeymoon, or comedians Pat \& Patachon's visit to a number of schools on the occasion of a new release; in order to 'learn' more about stars' private lives, the popular Photoplay series ONZE FILMSTERREN offered a peep behind the scenes. There is also a number of films that have the wider film industry as their subject. See, for example: HOLlYWOOD KEURT STERREN (tests of new talent) and various episodes of PARAMOUNT VARIETIES. Some of these were actually hardly distinguishable from commercials, such as IT HAPPENED IN HOLLYWOOD, MISS HOLLYWOOD 1937 or SECRETS DE MAQUILLAGE D'HOLLYwOod, all praising the importance of Max Factor's make-up to Hollywood careers.

6 Some Dutch examples are: GROOTSE PLANNEN! GROOTSE DADEN! (about the building of the City Theatre in Amsterdam); OPENING VAN HET CITY THEATER TE AMSTERDAM; VAN HOPJESFABRIEK TOT BIOSCOOP THEATER (about the building of the West-End Theatre in The Hague); I-JARIG BESTAAN WESTEND THEATER (announcement of a special anniversary programme); BOUW CAPITOL THEATER; DE PREMIÈRE VAN DOOD WATER IN HET PASSAGE THEA- 
TER, SOL KINSBERGEN (announcing the Passage Theatre's manager's silver jubilee), MET SCHOOL NAAR DE FILM (about school children visiting a cinema), as well as trailers and a number of textual trailers that hype or explain aspects of a theatre's policy (its 'first choice of the best productions of the world market', its special children matinees, its protest against law enforcement in matters of censorship, or why it discontinued its advertisements in a particular newspaper).

7 Steve Wurtzler, "She sang live, but the microphone was turned off": the live, the recorded and the subject of representation', in: Rick Altman (ed.), Sound theory sound practice, New York-London 1992, p. 96.

8 As the significance of these films was primarily local, there are, of course, only Dutch productions in the film collection of the Nederlands Filmmuseum. See, for example: REDE BURGEMEESTER FOCKEMA ANDREAE (speech on the occasion of the re-opening of a cinema in Utrecht); TOESPRAAK I. COHENBARNSTIJN (the manager of a cinema in Utrecht wishes his spectators a happy New Year and informs them that they are in the first theatre equipped with hearing aids as well as that he has the town's monopoly on dubbing foreign films); VERBOUWING VAN 'DE HARMONIE' TE LEEUWARDEN, MEI-SEPT. I937, Or HET WOORD IS AAN DR. W. DE VLUGT, BURGEMEESTER VAN AMSTERDAM (extolling the virtues of the Cineac actuality theatre).

9 In Amsterdam screenings this suggestion may have been particularly convincing, given the fact that the Carlton Hotel is near what used to be an area with a high concentration of cinemas in that town - the Rembrandtsplein.

Io See, for example: William Uricchio, 'Ways of seeing: the new vision of early nonfiction film', in: Daan Hertogs \& Nico de Klerk (eds.), Uncharted territory: essays on early nonfiction film, Nederlands Filmmuseum, Amsterdam 1997, p. I19-13I.

II See my: 'A few remaining hours: news films and the interest in film technology in Amsterdam film shows, 1896-1910', in: Film History, vol. II no. I, 1999, p. 5-18.

12 Some examples are: NEDERLANDSCHE VEREENIGING VOOR LUCHTBESCHERMING (DUTCH SOCIETY FOR AIR-RAID PROTECTION); inviting spectators to make up a catch phrase and buy lottery tickets); GELUIDEN VRAGEN UW AANDACHT! (a sound quiz); NETJES WEGGAAN A.U.B. (an animated instruction on how to leave the theatre); GODSHUIZEN BRANDEN (asking audiences to donate money in aid of Jewish refugees), as well as the numerous films for the so-called Bio holiday resort, originally an initiative of Amsterdam cinema theatres to provide a holiday for Amsterdam slum children, later continued on a national scale; over time the purpose of these films became the financing of a holiday resort for handicapped children. The Bio holiday resort films were never shown without the familiar rattle of money boxes being passed through the auditorium (a tradition, in fact, that went on until well into the 1980s).

13 A good example is the trailer for the 1939 Deanna Durbin vehicle IT's A DATE, which harks back to Durbin's earlier roles since 1936 in order to prepare the spectator for a change of image, as it leads up to Durbin's latest, more mature role.

14 See for a particularly interesting and entertaining account Leslie Halliwell's autobiographical Seats in all parts: half a lifetime at the movies, London, 1985.

Is Brian Winston has calculated that, for instance, one series of canonical films, the British documentaries supervised by John Grierson for the EMB and GPO, was widely unseen. See: Claiming the real: the documentary film revisited, London 1995 , p. 6I-68. 